\title{
Flight Range Extension in Polistes simillimus Zikán, 1951 (Hymenoptera, Vespidae)
}

\author{
Fábio Prezoto ${ }^{1 *}$ and Nivar Gobbi ${ }^{2}$ \\ ${ }^{1}$ Departamento de Zoologia; Instituto de Ciências Biológicas; Universidade Federal de Juiz de Fora; Campus \\ Universitário-Martelos; 36.036-900; fprezoto@icb.ufjf.br; Juiz de Fora - MG - Brasil. ${ }^{2}$ Centro de Estudos \\ Ambientais; Universidade do Estado de São Paulo; Rio Claro - SP - Brasil
}

\begin{abstract}
The aim of this study was to determine the flight range extension of the social wasps, Polistes simillimus. The results of the 125 wasps-carried out tests originating from 10 colonies in post-emergency stage demonstrated that the flight range extension of $\mathrm{P}$. simillimus was of approximately $150 \mathrm{~m}$, resulting in a collection area of about $70.650 \mathrm{~m}^{2}$ by colony. It suggested wasp's efficiency as a biological control agent.
\end{abstract}

Key words: Social wasps, Polistes simillimus, flight range extension, nest return.

\section{INTRODUCTION}

Social wasps are considered main predatory insects and are important in the biological control of agricultural insects pests (Marques, 1996; Prezoto, 1999; Andrade and Prezoto, 2001). Several studies (Prezoto et al., 1994; Giannotti et al., 1995; Prezoto and Machado, 1999) revealed the preferences of Polistes Latreille, 1802 wasps against Lepidoptera caterpillars, emphasizing its efficiency as a natural enemy of these insects. The capture of preys is an important part of foraging behavior, which also involves complex activities such as prey recognition and homing ability (Wilson, 1971; Ugolini and Cannicci, 1998). Although there are studies concerning Polistes wasps foraging activities (Gobbi, 1977; Prezoto et al., 1994; Giannotti et al., 1995; Prezoto, 1997; Andrade and Prezoto, 2001), there are few researches concerning the flight range extension of these species (Gobbi, 1978; Giannotti, 1992; Santos et al., 1994).
In Brazil, the social wasps, Polistes (Aphanilopterus) simillimus Zikán, 1951 occurs from the State of Bahia to the State of Rio Grande do Sul. They can also be found in Paraguay, Argentina and Bolivia (Richards, 1978). Despite its wide distribution in South America, little is known about its biology, ecology and behavior. This study aimed to determine the flight range extension of $P$. simillimus and to provide data for its use in the biological control of agricultural plagues.

\section{MATERIAL AND METHODS}

The experiments were carried out in the Parque Estadual do Ibitipoca (Ibitipoca State Nature Reserve), State of Minas Gerais (21.42'30"/ $21^{\circ} 40^{\prime} 10^{\prime \prime} \mathrm{NS}$ and $\left.43^{\circ} 52^{\prime} / 43^{\circ} 54^{\prime} \mathrm{W}\right)$, Brazil, during the months of January and February 2000. The area has small-sized trees, bushes, traffic tracks, and human constructions of several dimensions.

\footnotetext{
* Author for correspondence
} 
One hundred twenty five mature females of $P$. simillimus wasps were randomly captured on ten colonies in post-emergency stage located in human constructions of the studied area. In order to identify the individuals, the wasps were captured with the use of an entomological net and were individually marked on the mesosome with ACRILEX® plastic ink. The individuals were put in a large month glass bottle in which they stayed until the moment to be set free (about half hour) at predetermined distances such as 50,100, 150, 200, 250,300 , and $500 \mathrm{~m}$ from the original nest. The liberation of the wasps happened at the hottest hours of the day, between 10 to 12 hours, what favors the flight of this insects. The returning percentage was calculated based on the direct counting of the marked individuals. The counting was finished 48 hours after the release.

\section{RESULTS AND DISCUSSION}

The results related to the returning capacity of $P$. simillimus swarming wasps are show in Table 1. Some wasps came back immediately to the nest, while the forragers took a longer period to come back. This delay, in the most of the cases, was justified by the foraging activity, since the individuals that were removed from the colony became stimulated to perform the foraging activity. It allowed to identify the kind of materials that the wasps brought back to the nest such as water, pulp of wood, nectar, and prey. This foraging stimulation was also observed in $P$. versicolor (Gobbi, 1977) and P. lanio (Giannotti, 1992) flight range extension studies. In few cases it was possible to observe the foraging wasps return in the day after the experiment, resembling the case registered by Santos et al. (1994) for $P$. canadensis.

The results indicated that after of $200 \mathrm{~m}$ of distance from nest, the return rates stars to decrease. In each group of wasps released in a distance of $300 \mathrm{~m}$ only one came back to the nest, and in each group of 10 foragers wasps released in a distance of $500 \mathrm{~m}$ none of them came back (Table 1). The Spearman correlation test demonstrated a negative correlation between the distance enlargement and the percentage of returns $(r=-1.00 ; p=0.0004)$.

The large number of individuals unable to come back to colony $(n=61 ; 48.8 \%)$, frequently starting from a distance of $150 \mathrm{~m}$, could be related to the presence of immature individuals in the colonies. It is known that in Polistes wasps the foraging behavior begins in the second/ third week of their lives (Giannotti and Machado, 1994; Sinzato, 2002). Thus, the manipulation of immature wasps (first weeks of life) could interfere in the gained results, due to their lack of experience regarding these activities. This task requires from the individual a high capacity of visual marks memorization (Ugolini, 1987) that will facilitate its homing ability.

Gobbi (1977, 1978) found in $P$. versicolor effective flight range of extension around $200 \mathrm{~m}$, and registered $850 \mathrm{~m}$ as a maximum returning distance. Giannotti (1992) sugested that P. lanio flight range extension was around $200 \mathrm{~m}$, since he registered $100 \%$ of returns from a distance of $100 \mathrm{~m}, 90 \%$ and $80 \%$ from distances of 150 and 200m, respectively. Santos et al. (1994), however, demonstrated that $P$. canadensis wasps were able of foraging activities from $650 \mathrm{~m}$ distance from the nest and that when they got more than $250 \mathrm{~m}$, their percentage of swarming wasps return suddenly reduced.

Suzuki (1978) observed that $P$. chinensis antennalis used a $120 \mathrm{~m}^{2}$ area. Kasuya (1980), however, studying the same species, registered that the foraging activities were carried out in a $20 \mathrm{~m}$ range. Hibino (1981) observed that $P$. jadwigae foraging activity was up to $48.2 \mathrm{~m}$ from the colony. Ugolini (1986) sugested that $P$. dominulus $(=$ gallicus $)$ wasps presented a high homing ability when they were released in distances of 300/400m from their nests.

Based on the results of this study and of literature, it could be, that Polistes wasps used, more efficient, food sources located in the colony surroundings, which varied between 20 and $650 \mathrm{~m}$ from the nest. However, 120/200m seemed to be the feasible distance in terms of energy spending.

$P$. simillimus effective flight range extension was of around $150 \mathrm{~m}$ since most of the foragers wasps returns $(\mathrm{n}=52 ; 41.6 \%)$ took place up to this distance. Thus, $P$. simillimus hypothetical explored area in the foraging activity was around $70,650 \mathrm{~m}^{2}$. It could, thus, be concluded that $P$. simillimus colonies could be used in the biological control of insects pests if they were put in a medium distance of $150 \mathrm{~m}$ from each other, assuring the efficient occurrence of swarming activity in this area. 
Table 1 - P. simillimus wasps returning capacity carried out in post-emergency phase colonies.

\begin{tabular}{cccc}
\hline $\begin{array}{c}\text { Tried } \\
\text { Distance }(\mathbf{m})\end{array}$ & $\begin{array}{c}\text { Number of } \\
\text { Released individuals }\end{array}$ & $\begin{array}{c}\text { Number } \\
\text { of returns }\end{array}$ & Returns (\%) \\
\hline 50 & 30 & 26 & 86.67 \\
100 & 20 & 14 & 70 \\
150 & 20 & 12 & 60 \\
200 & 20 & 8 & 40 \\
250 & 15 & 3 & 20 \\
300 & 10 & 1 & 10 \\
500 & 10 & 0 & 0 \\
\hline
\end{tabular}

\section{ACKNOWLEDGMENTS}

The authors thank to $\mathrm{CNPq}$ (Conselho Nacional de Desenvolvimento Científico e Tecnológico) for the financial support.

\section{RESUMO}

O comportamento de sair da colônia para o forrageio de materiais e a capacidade de retornar ao ninho é uma atividade complexa exibida pelas vespas sociais. O objetivo deste estudo foi determinar o raio de ação da vespa social $P$. simillimus. Os resultados dos testes com 125 vespas provenientes de 10 colônias em fase de pós-emergência, demonstraram que o raio de ação de $P$. simillimus é de aproximadamente 150 metros ao redor da colônia, resultando em uma área de forrageio com cerca de $70.650 \mathrm{~m}^{2}$ por colônia, o que provem informações importantes para o manejo dessas colônias para o controle biológico em agrossistemas.

\section{REFERENCES}

Andrade, F. R. and Prezoto, F. (2001), Horários de atividade forrageadora e material coletado por Polistes ferreri Saussure, 1853 (Hymenoptera, Vespidae), nas diferentes fases de seu ciclo biológico. Rev. Bras. Zoociências, 3, 117-128.

Giannotti, E. (1992), Estudos biológicos e etológicos da vespa social neotropical Polistes (Aphanilopterus) lanio lanio (Fabricius, 1775) (Hymenoptera, Vespidae). Tese (Doutorado). Universidade Estadual Paulista, Rio Claro, São Paulo, Brazil.

Giannotti E. and Machado, V. L. L. (1994), Longevity, life table and age polyethism in Polistes lanio lanio (Hymenoptera: Vespidae), a primitive eusocial wasp. J. Adv. Zool., 15, 95-101.
Giannotti, E.; Prezoto, F. and Machado, V. L. L. (1995), Foraging activity of Polistes lanio lanio (Fabr.) (Hymenoptera, Vespidae). An. Soc. Entomol. Brasil, 24, 455-463.

Gobbi, N. (1977), Ecologia de Polistes versicolor (Hymenoptera, Vespidae). Tese (Doutorado). Universidade de São Paulo, Ribeirão Preto, São Paulo, Brazil.

Gobbi, N. (1978), Determinação do raio de vôo de operárias de $P$. versicolor (Hymenoptera, Vespidae). Ciência e Cultura, 30, 364-365.

Hibino, Y. (1981), Foraging behavior of the Japanese paper wasp Polistes jadwigae Dalla Torre (Hymenoptera, Vespidae). Jap. J. appl. Ent. Zool., 25, 89-93.

Kasuya, E. (1980), Behavioral ecology of Japanese paper wasp, Polistes spp. (Hymenoptera, Vespidae). I. Extranidal activities of Polistes chinensis antennalis. Res. Popul. Ecol., 22, 242-254.

Marques, O. M. (1996), Vespas sociais (Hymenoptera, Vespidae): características e importância em agrossistemas. Insecta, 5, 18-39.

Prezoto,F. (1997), Ação de Polistes (Aphanilopterus) simillimus Zikán, 1951 (Hymenoptera, Vespidae) no combate às pragas de Zea mays L. Dissertação (Mestrado). Universidade Estadual Paulista, Rio Claro, São Paulo, Brazil.

Prezoto, F. (1999), A importância das vespas como agentes no controle biológico de pragas. Rev. Biotecnologia, Ciência and Desenvolvimento, 2, 24-26.

Prezoto, F. and Machado, V. L. L. (1999), Ação de Polistes (Aphanilopterus) simillimus Zikán (Hymenoptera, Vespidae) no controle de Spodoptera frugiperda (Smith) (Lepidoptera, Noctuidae). Revta. bras. Zool., 16, 841-851.

Prezoto, F.; Giannotti, E. and Machado, V. L. L. (1994), Atividade forrageadora e material coletado pela vespa social Polistes simillimus Zikán, 1951 (Hymenoptera, Vespidae). Insecta, 3, 11-19.

Richards, O. W. (1978), The social wasps of the Americas excluding the Vespinae. London: British Museum (Natural History). 
Santos, G. M. M.; Marques, O. M. and Carvalho, C. A. L. (1994), Raio de ação de Polistes canadensis canadensis (L., 1758) (Hymenoptera, Vespidae). Insecta, 3, 20-24.

Sinzato, D. M. S. (2002), Comportamento de Polistes (Aphanilopterus) ferreri Saussure, 1853 (Hymenoptera, Vespidae) durante as diferentes fases de desenvolvimento do ciclo biológico da colônia. Dissertação (Mestrado). Universidade Federal de Juiz de Fora, Juiz de Fora, Minas Gerais, Brazil.

Suzuki, T. (1978), Area, efficiency and time foraging in Polistes chinensis antennalis Perez (Hymenoptera, Vespidae). Japanese Journal of Ecology, 28, 179-189.

Ugolini, A. (1986), Homing ability in Polistes gallicus (L.) (Hymenoptera, Vespidae). Monitore zool. Ital., 20, 1-15.

Ugolini, A. (1987), Visual information acquired during displacement and initial orientation in Polistes gallicus (L.) (Hymenoptera, Vespidae). Anim. Behav., 35, 590-595.

Ugolini, A. and Cannicci, S. (1998), Homing in paperwasps. In: S.Turillazzi and M.J.West-Eberhard (Eds.) Natural history and evolution of paper-wasps. Oxford: Oxford University Press. pp. 126-143.

Wilson, E. O. (1971), The insect societies. Cambridge: The Belknap Press.

Received: May 21, 2004; Revised: January 13, 2005. Accepted: May 17, 2005. 